\title{
TOWARDS A COMMON UNDERSTANDING OF 'EMERGING FARMER' IN A SOUTH AFRICAN CONTEXT USING DATA FROM A SURVEY OF THREE DISTRICT MUNICIPALITIES IN THE EASTERN CAPE PROVINCE
}

\author{
Zantsi, S. ${ }^{1}$, Greyling, J. C. and Vink, N. \\ Correspondence author: S. Zantsi. Email: siphez@sun.ac.za
}

\begin{abstract}
The objective of this study was to improve our understanding of the diversity among emerging smallholders using various commonly used indicators. These were reviewed and applied to a sample of 379 emerging smallholders situated in three major smallholding districts within the Eastern Cape Province of South Africa. It was found that the typical emerging farmer has the following profile: He is black, situated in a former homeland and is 58 years old. The typical farmer cultivates field crops as a secondary source of food and income, but keeps livestock as primary and secondary sources of income. The average emerging smallholder mostly grows maize for own consumption given a crop commercialisation index (CCI) of 0.66 and sells a greater portion of his cabbage and potatoes given CCIs of 0.73 and 0.83 respectively. The average emerging farmer earns a net income of $R 26600$ per year, but there is an income inequality, since the most successful farmer earns 26.7 times the average income. This translates to a Ghini coefficient of 0.48, which is high by international standards, but low compared to the South African average of 63.1. When speaking to fellow farmers, it was found that $78 \%$ of them feel constrained by farming in a homeland, but only $72 \%$ would be willing to move from their homeland, with most (45\%) saying that they would only do so if they were provided with sufficient government support.
\end{abstract}

Keywords: Eastern Cape Province, Emerging farmer, Survey

\section{INTRODUCTION}

\subsection{Background and research problem}

South African agriculture is characterised by 'two agricultures' with the one consisting of highly capitalised, large-scale and mostly white farmers, and the other comprising of black smallholders who mostly find themselves in the former homeland areas (Lipton, 1977). Whilst this dualism has a historic origin, it persists to the present despite the focus of the government to develop and support smallholders. Whilst this failure can be attributed to various executional challenges such as weak agricultural extension services and limited support budgets (Aliber \& Hart, 2009), it is also caused by poor project design because of the assumption that smallholders form one homogeneous group. The reality is that smallholders are members of a diverse group of farmers who range from a large group of subsistence farmers on one side of the spectrum to a smaller group of commercially-orientated smallholders on the other side. The main difference between these two groups, other than the scale of production, is the reason for engaging in production, whereas the former produces to improve their household food security whilst the latter produces to sell, given that it serves as their primary or secondary sources of income

\footnotetext{
${ }^{1}$ Department of Agricultural Economics, Stellenbosch University, Private Bag X1, Matieland, 7602, E-mail: siphez@sun.ac.za
} 
(Nieuwoudt, 2000; Van Averbeke \& Mohamed, 2006). Between these extremes is a group of so-called 'emerging smallholders' who are market-orientated produce sellers who aspire to commercialise their produce (Nieuwoudt, 2000; Senyolo, 2007; Van Averbeke \& Mohamed, 2006). This categorisation is not unique to South Africa since it is also present among Asian farmers (Pingali \& Rosegrant, 1995).

While this categorisation intuitively makes sense, there is a fair degree of confusion in the literature. For example, some studies use the terms of emerging and subsistence farmers interchangeably (Khapayi \& Celliers, 2016), while others equate emerging farmers to land reform beneficiaries (Macleod, McDonald \& Van Oudtshoorn, 2008; Mohlatlole, Dzomba \& Muchadeyi, 2015; Xaba \& Dlamini, 2015), or simply view all black farmers who are operating in disadvantaged circumstances compared with their white counterparts as emerging farmers (Rother, Hall \& London, 2008). Hence, more should be done to improve the definition of the respective farmer groups.

To improve our understanding of the diversity among smallholders as well as the way in which we distinguish between them is important for several reasons. Firstly, it will enable improved programme design and provide targeted extension support. Secondly, knowing the number of smallholders who find themselves in the respective sub-groups will enable policy makers to prioritise support spending. Thirdly, it will improve the process of incorporating emerging smallholders in the land reform programme since they have been identified as well-suited potential beneficiaries (Cousins, 2015). Whilst this is not the first study concerning itself with the definition of smallholders (Cousins, 2010; Kirsten \& Van Zyl, 1998), this is the first that focusses on emerging smallholders. To avoid the pitfalls of some of the previous studies, a multifaceted approach was taken, thereby minimising the risk of misallocation and improving the framework's ability to shed more light on the characteristics of emerging smallholders.

\subsection{Objectives and structure}

The objective of this study was to improve our understanding of the diversity among emerging smallholder farmers (this also includes commercial smallholders) using various commonly used indicators. To this end, the commonly used smallholder classification measures were reviewed and applied to a sample of emerging smallholders, after which these were integrated into a unified framework. The sample consisted of 379 emerging smallholder households which were randomly selected in three major smallholder districts within the Eastern Cape Province of South Africa.

\section{WHY DO EMERGING FARMERS MATTER?}

The South African agricultural sector is in the process of transformation, decolonising the sector from decades of neglect, suppression and discrimination against black farmers through instruments that excluded them from participating in the mainstream economy and from legal ownership of land, such as the 1913 Land Act (Vink \& Van Zyl, 1998). After the democratically elected government in 1994, transformation policies were put in place to remedy the injustices of the past. These transformation policies manifest through the Land Reform Policy and the other support measures intended to aid previously disadvantaged farmers. In the land redistribution pillar of the Land Reform Policy, emerging farmers are identified as the potential beneficiaries, although not much is understood about who they are. 
Hence, this section emphasises the importance of emerging farmers in the South African agricultural sector.

\subsection{Poverty reduction}

The South African communal farming areas (where most of the emerging farmers live) are characterised by poverty and a lack of employment opportunities. As such it has been argued that since many poor people live in the rural areas and many are already engaged in some form of farming activities, agriculture is a viable tool to fight rural poverty (Diao, Hazell \& Thurlow, 2010; Machethe, 2004; World Bank, 2007). Evidence from Asia's Green Revolution has also shown that agriculture can be used as a motor to drive rural economic growth and development (Hazell, 2009). This can be achieved along many avenues of which one is increasing rural incomes, as agriculture creates a demand for non-farm goods and a supply of food which improves food security.

\subsection{Creating employment opportunities}

The commercial agricultural sector in South Africa has shown a strong trend of job shedding in the past few decades. This can be the result of many factors such as intensive use of machinery which reduces unskilled labour among other factors (Conradie, 2007; Sandrey et al, 2011). Given this trend in commercial agriculture, the smallholder who tends to be labour intensive can contribute towards creating jobs in agriculture. Since emerging farmers use fewer machines, they require more labour compared to their commercial counterparts. Moreover, there are more emerging farmers than commercial farmers. Therefore, although they employ fewer workers individually, the collective number of labourers is significantly high. Finally, empirical research has found that livestock communal farming has the capacity to create jobs for the rural poor, and in this respect, the Eastern Cape has the highest capacity compared to other provinces (Mmbengwa et al, 2015). One way to increase employment opportunities is to stimulate the rural economy through demand-led growth. According to chapter six of the National Development Plan (NDP), agriculture is one of the industries that has the highest potential for job creation. It is envisaged that emerging farmers will create 165000 primary jobs and 82500 jobs in secondary employment (National Planning Commission (NPC), 2011).

\subsection{Demand-led growth}

There is a link between the agricultural and the non-agricultural sectors created by the market forces of supply and demand. As such, the expansion of the agricultural sector has the ability to stimulate growth in the non-agricultural sector which has a poverty reducing effect. Hendricks (2002) has shown that an increment in rural households' income has the potential to stimulate spending in non-tradable goods and thus contributes to local economic growth.

Furthermore, Rosegrant and Hazell (2000) found a strong impact of agriculture in rural development in countries where small-scale farms dominate. In this respect, increasing the productivity of emerging farmers can increase the demand for inputs used in production such as fertilisers, pesticides and labour, if the constraints facing them are addressed and given welldeveloped support. Moreover, this will reduce unemployment and increase the supply of food contributing to rural food security, which is a serious problem in rural areas of South Africa. However, for this to happen, there needs to be efficient use of resources among other factors. 
S. Afr. J. Agric. Ext.

Vol. 47 No. 2, 2019: 81 - 93

http://dx.doi.org/10.17159/2413-3221/2019/v47n2a505
Zantsi, Greyling,

Vink

(License: CC BY 4.0)

\subsection{Efficient use of resources}

Empirical evidence from the Eastern Cape shows that small-scale farmers are at least competitive and efficient in some activities such as horticultural, field crops and livestock products (Ngqangweni, 1999). In addition, the Bureau for Food and Agricultural Policy (BFAP, 2017) shows that small-scale communal broiler farmers achieve better profit margins than their large commercial counterparts. Ngqangweni (1999) also found a strong growth linkage between farming and the rural non-farm economy, which he describes as one that can lead to under-utilised resources being put into production if well-developed support is given and the barriers are removed.

However, there is overwhelming evidence of under-utilised land in the Eastern Cape that can be put under production if emerging farmers' challenges are addressed and a well-developed farmer support system is designed (Andrew \& Fox, 2004; Connor \& Mtwana, 2018; De La Hey \& Beinart, 2017). In order for emerging farmers to achieve the above roles, agricultural extension would have to play a role.

\subsection{Role of agricultural extension in developing emerging farmers}

The NDP emphasises the need to train extension officers who can respond to the needs of smallholders (NPC, 2011). This highlights the importance of addressing the needs of a specific group of farmers by paying attention to getting to know them better. This is important since understanding the client determines the appropriateness and relevance of the advisory service to be rendered by an extension officer. However, literature shows differing perspectives with regards to a common understanding of what an emerging farmer in South Africa actually is. In the study of Rother et al (2008), extension officers were asked what an emerging farmer is to their knowledge, and they all provided different definitions. Therefore, a common understanding of what emerging farmers are is important to the agricultural extension field as they have an important role to play in developing emerging farmers by rendering a relevant and appropriate advisory service.

\section{METHODOLOGY}

\subsection{Data}

Non-subsistence smallholders were interviewed during 2017 in three districts of the Eastern Cape Province using a questionnaire that had been compiled in English and administered in isiXhosa. The Eastern Cape was selected as $21,3 \%$ of all smallholders are situated in the province, which makes it the second most important smallholder province after KwaZuluNatal, which has $23 \%$ of all smallholders (Statistics South Africa, 2016). A total of 379 farmers were surveyed at random in the three primary smallholder districts of the province, with 175 being in the Amathole District Municipality, 84 in the Oliver Regional Tambo District Municipality, and 120 in the Chris Hani District Municipality. Only market-orientated smallholders were interviewed. In order to qualify, they had to have sold produce during the previous season. This was to ensure that farmers who at least had some degree of commercial orientation were interviewed. 
S. Afr. J. Agric. Ext.

Vol. 47 No. 2, 2019: 81 - 93

http://dx.doi.org/10.17159/2413-3221/2019/v47n2a505
Zantsi, Greyling,

Vink

(License: CC BY 4.0)

\subsection{Approach and data analysis methods}

Based on the national and international literature reviewed, South African smallholders can be categorised according to four themes: i) population group, farm location and land size, ii) main reason for farming, iii) farm turnover, and iv) commercial orientation. The literature relevant to each theme is discussed in the next section, followed by its application to the survey results. In addition, a fifth theme, namely the willingness to move to a land reform project, is introduced and analysed.

\section{RESULTS AND DISCUSSION: SMALLHOLDER CHACTERISATION}

\subsection{Population group, age, sex, farm location and size}

Smallholding farming is generally associated with black farmers (Khapayi \& Celliers, 2016; MacLeod et al, 2008; Xaba \& Dlamini, 2015). This is also reflected in government programmes that target emerging farmers, for example the Comprehensive Agricultural Support Programme (CASP) (Department of Agriculture, Forestry and Fisheries (DAFF), 2015). It was found that $66 \%$ of emerging farmers are men with an average age of 58 years. This stands in contrast to studies on subsistence smallholders in general which found that $60 \%$ are women and their average age is 55 to 59 years (Aliber \& Hart, 2009).

Furthermore, a smallholding is often associated with being a backward, unproductive and noncommercial endeavour that is undertaken as a means of subsistence on small pieces of land in the former homeland areas (Kirsten \& Van Zyl, 1998). After the democratic transition, this definition has been extended to also include land reform beneficiaries (Cousins, 2010). Hence, to qualify as a smallholder, a person must be black and situated in a former homeland or on a land reform farm. Therefore, all the farmers surveyed in this study would qualify as smallholders. However, these assumptions can be easily refuted. For example, Kirsten and Van Zyl (1998) showed that even though all white farmers were deemed commercial, large homeland farmers were bigger than the smallest subgroup of "commercial" farmers who cultivated less than 10 hectares. This was also echoed by Pienaar and Von Fintel (2014) who use the Statistics South Africa household survey to show that, whilst most homeland smallholders cultivate an area of less than a hectare, there is a subclass of about 5300 who cultivate more than 10 hectares. This is also in line with our results since, on average, farmers cultivated an area of 2.7 hectares, whilst the largest farmer had 30 hectares under production.

\subsection{Income and turnover}

Whilst distinguishing between farmers based on farm size or cultivated land has the advantage of simplicity, it is flawed from an economic perspective since it does not take differences in land quality or enterprise into account. For example, one hectare of irrigated land used for vegetable farming will have a much higher profit potential than 500 hectares of land used for extensive livestock farming in the Karoo. Hence, turnover or net farm income should preferably be used to distinguish between farms (Kirsten \& Van Zyl, 1998). Subsequently, Kirsten (2011) used income to distinguish between farmers, arguing that an annual turnover of R500 000 marks the threshold between a smallholding and commercial farms. Whilst classifying farmers by turnover is a better gauge than physical farm size, it is still a sub-optimal indicator since it is subject to enterprise-specific structural properties. For example, dairy farms typically have a high turnover but a low profit margin, whilst the opposite is true for an extensive sheep farm 
during a normal year. Therefore, if available, it is better to use net farm income as the distinguishing metric.

Figure 1 portrays the 2016 net farm income of the respective smallholders surveyed for this study. It is sorted in ascending order, with the sample average and median indicated by the dashed and dotted lines respectively. It indicates that the worst performing smallholder lost a total of R67 000 whilst the best performing farmer netted a total of R776 000. Collectively, smallholder profit exhibited a highly unequal return, which can be categorised as a pareto distribution since most smallholders earn a relatively low net farm income relative to the best performing farmer. This is also evidenced by the relatively low average net farm income of R45 200 in 2016 and median net farm income of R29 600 given the skewed distribution.

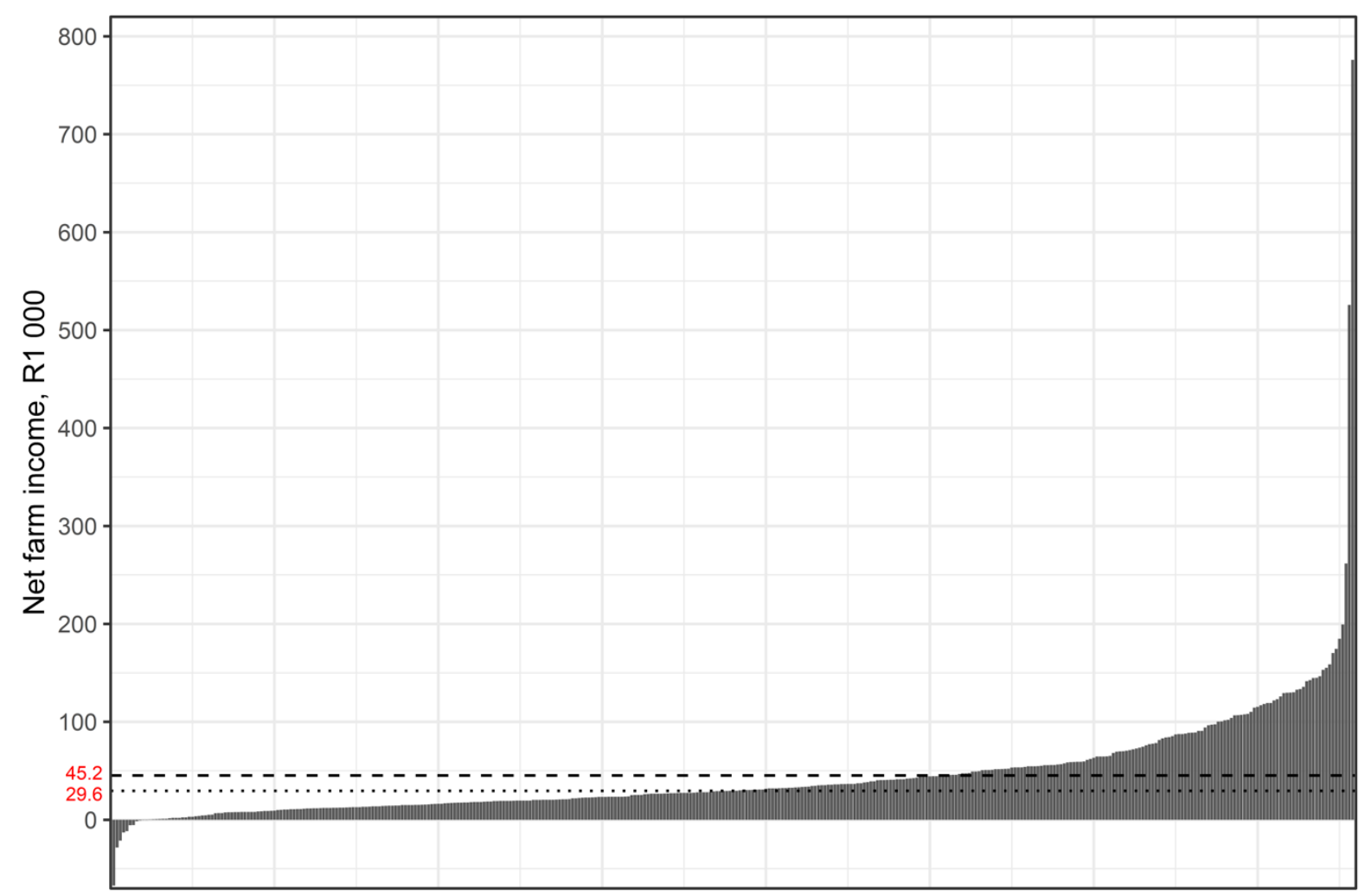

Figure 1: Household net farm income

The extent of the farmer income inequality as shown in Figure 1 can be quantified through calculating the Gini coefficient of the farmers surveyed. First devised by the Italian statistician, Corrado Gini in 1912, the Gini coefficient is commonly used by economists for comparing the income inequality of countries. Per definition, the coefficient can take a value of between 0 and 1 , with the former reflecting a population wherein income is distributed equally whilst the latter shows a highly unequal income distribution wherein a select few earn most of the income. For comparative purposes, during the ten years ending in 2017, South Africa, Botswana and Namibia had the highest average Gini coefficients of all countries tracked by the World Bank globally at 63.1, 60.5 and 60.0 respectively. Inversely, the Czech Republic, Slovenia and Ukraine had the lowest average of 25.0, 25.2 and 26.2 respectively during this period (World Bank, 2018). The coefficient is calculated by fitting a so-called Lorenz curve to the data and 
comparing it to the ideal situation wherein the income is distributed equally within the population. The coefficient is calculated as follows (Dorfman, 1979):

$$
G=\frac{A_{e}-A}{A_{e}}
$$

where $G$ represents the Gini-coefficient, $A_{e}$ shows the area under the Lorenz curve of a population with an equal income distribution and $A_{e}$ shows the area under the Lorenz curve of the actual income distribution. The income inequality of the farmers' surveys was calculated at $48.9^{2}$, thus the distribution of smallholder net farm income is not as unequal as South Africa as a whole. It must be noted that this does not represent the income distribution of households, since it would have to include non-farm income, remittances and grants. This finding simply underscores the fact that the net farm income of emerging smallholders shows substantial diversity, and the relatively large incomes both challenge the notion that smallholders are backward and provide extension officers with a benchmark.

\subsection{Main reason for farming}

The classification of smallholders according to their primary reasons for engaging in farming has been widely used in South Africa (Aliber \& Hart, 2009; Statistics South Africa, 2016). This is a good measure since it portrays the intent of farmers by distinguishing between subsistence and non-subsistence households based on their motivation for engaging in agricultural production. However, it cannot be used in isolation since it has to be viewed in combination with the percentage of produce sold. A smallholder who is motivated to engage in production, but sells a small portion of his/ her produce cannot be classified in the same category as the converse.

Figure 2 displays the main reasons for keeping livestock and engaging in crop production. If viewed simultaneously, these pie charts reveal striking differences. They show that most emerging smallholders (54\%) kept livestock as a secondary source of income, followed by keeping livestock as a main source of goods (38\%). In this respect, livestock was an unimportant primary (2\%) and secondary food source (4\%).

The opposite is true with regards to crop production where most farmers (31\%) do so for an extra source of food whilst the second-most important reason for producing was as a main source of food and income (27\%). A relatively small group of farmers (10\%) indicated that crop production served as a secondary source of income.

\footnotetext{
${ }^{2}$ The negative returns were excluded from the calculation.
} 


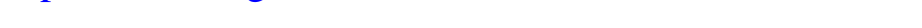

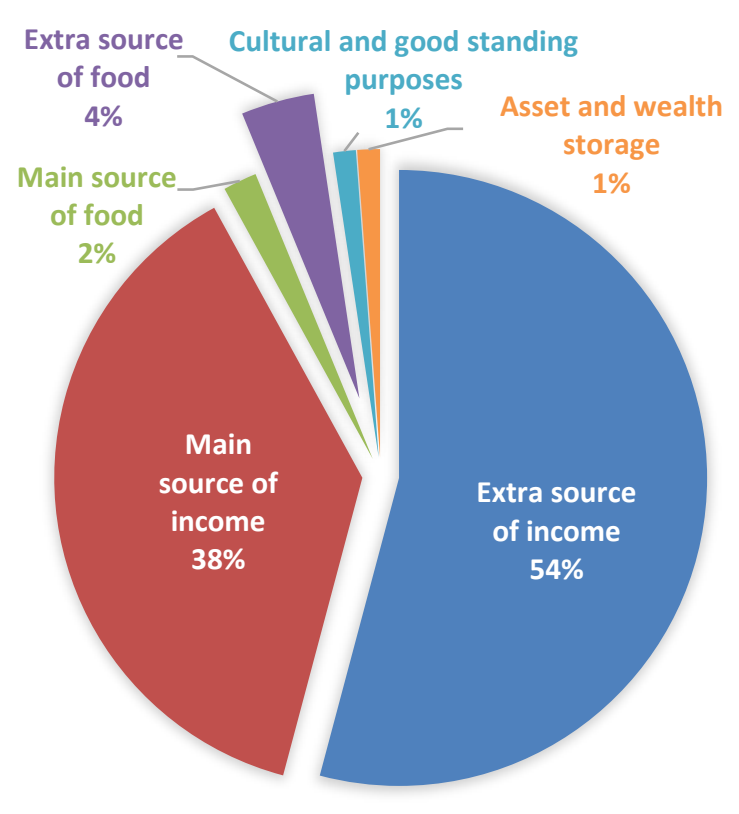

a) Main reasons for keeping livestock

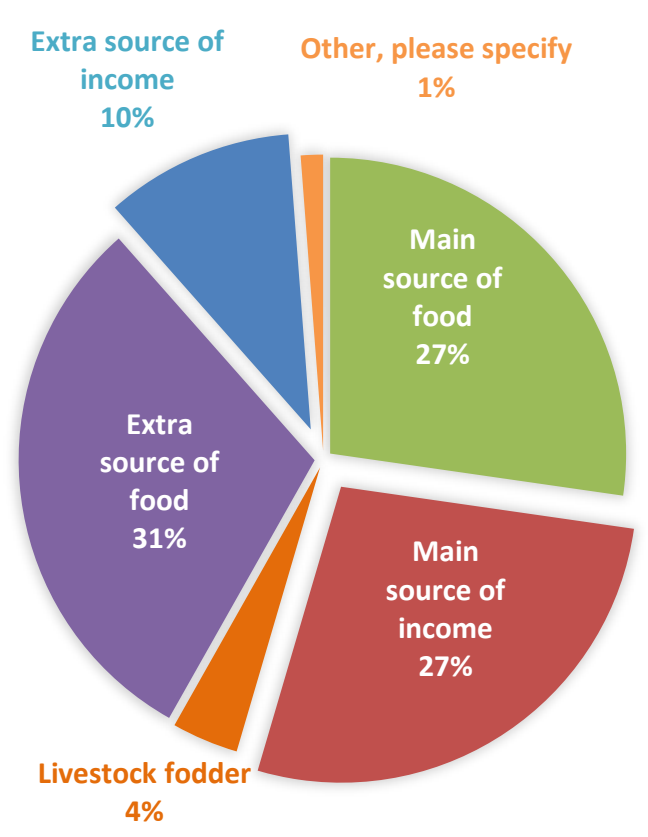

b) Main reasons for producing crops

\section{Figure 2: Reasons for engaging in crop and livestock production}

The importance of crop production as a food source is to be expected given that farmers mainly produce staple crops such as maize, cabbage and potatoes. The finding that livestock farming serves as a commercial endeavour for most farmers is important and should be incorporated in the design of farmer support programmes and extension strategies. The positive impact of such initiatives has already been proven by the National Wool Growers Association (NWGA) with the smallholder wool project that has improved both quality and quantity of smallholder wool production (De Beer \& Terblanché, 2015).

\subsection{Proportion of sold produce}

Internationally, various measures have been used to gauge the commercialisation of smallholders (Gebremedhin \& Jaleta, 2010; Jaleta, Gebremedhin \& Hoekstra, 2009; Von Braun, 1995). This study used the Crop Commercialisation Index (CCI) as applied by Govereh, Jayne and Nyoro (1999), as well as Dube and Guveya (2016), to assess the level of commercialisation in our sample. The CCI is calculated on a per crop basis whereby the annual total quantity sold is divided by the total production. Thus, the greater the CCI value, the greater the degree of commercialisation with a value of 1 indicating that all produce was sold. A CCI value of 0.5 is viewed as the transition point between subsistence and emerging commercial farmers (Gebremedhin \& Jaleta, 2010; Gevereh et al, 1999).

Since emerging farmers mainly engage in livestock production for a primary or secondary source of income (92\%), calculating a livestock CCI was deemed unnecessary. The CCI for maize, potatoes and cabbage as the main crops produced is shown in Table 1 . While maize is the crop produced by most farmers $(n=116)$, it is also the least commercialised crop and thus mainly serves as a household staple. Potatoes is the most commercialised crop given a CCI of 0.83 with the level of cabbage commercialisation calculated at 0.73 . On average, the farmers surveyed can be regarded as commercially-orientated given that the CCI is greater than 0.5 . 
S. Afr. J. Agric. Ext.

Vol. 47 No. 2, 2019: 81 - 93

http://dx.doi.org/10.17159/2413-3221/2019/v47n2a505
Zantsi, Greyling,

Vink

(License: CC BY 4.0)

Table 1: Crop Commercialisation Index (CCI) for major crop activities

\begin{tabular}{|l|c|c|c|c|}
\hline Activity & $\mathbf{N}$ & $\begin{array}{c}\text { Total output } \\
\text { sold }\end{array}$ & Total output & Mean CCI \\
\hline Maize (50 kg bags/ha) & 116 & 42.52 & 64.42 & 0.66 \\
\hline Potatoes (10 kg bags/ha) & 53 & 44.92 & 54.13 & 0.83 \\
\hline Cabbage (heads/ha) & 51 & 58.62 & 79.22 & 0.73 \\
\hline
\end{tabular}

\subsection{Intentions for expanding production}

Numerous studies have argued that poor beneficiary selection is one of the major causes for the failure of land reform projects (Binswanger-Mkhize, 2014; Hall, 2015) with some researchers reasoning that emerging smallholders in the former homelands are better suited potential beneficiaries (Cousins, 2015; Department of Rural Development and Land Reform, 2013). Whilst the aspirations of smallholders have been taken into consideration by some studies (Nieuwoudt, 2000; Senyolo, 2007), none have considered whether smallholders would be willing to move from their communal farm, and if so, under what circumstances. It is assumed that they would be willing to participate in land reform projects given the constraints that they face, such as limited access to capital due to insecure property rights (Cousins, 2015), high transaction costs (Khapayi \& Celliers, 2016), smallholding size (Fourie, Mahlako \& Van der Westhuizen, 2018), and the overutilisation of shared rangeland (Vetter, 2013).

As such, respondents were asked whether they feel constrained by these factors. The majority (78\%) indicated that they felt constrained by farming in a homeland area, but not all respondents who felt constrained were willing to move, since only $72 \%$ indicated that they would be willing to do so. With regards to the conditions for moving, $45 \%$ indicated that they would be willing to move if the government provided the necessary post-settlement support. A smaller, but significant group (28\%) indicated that they would be willing to move even if they had to pay rent for the land received.

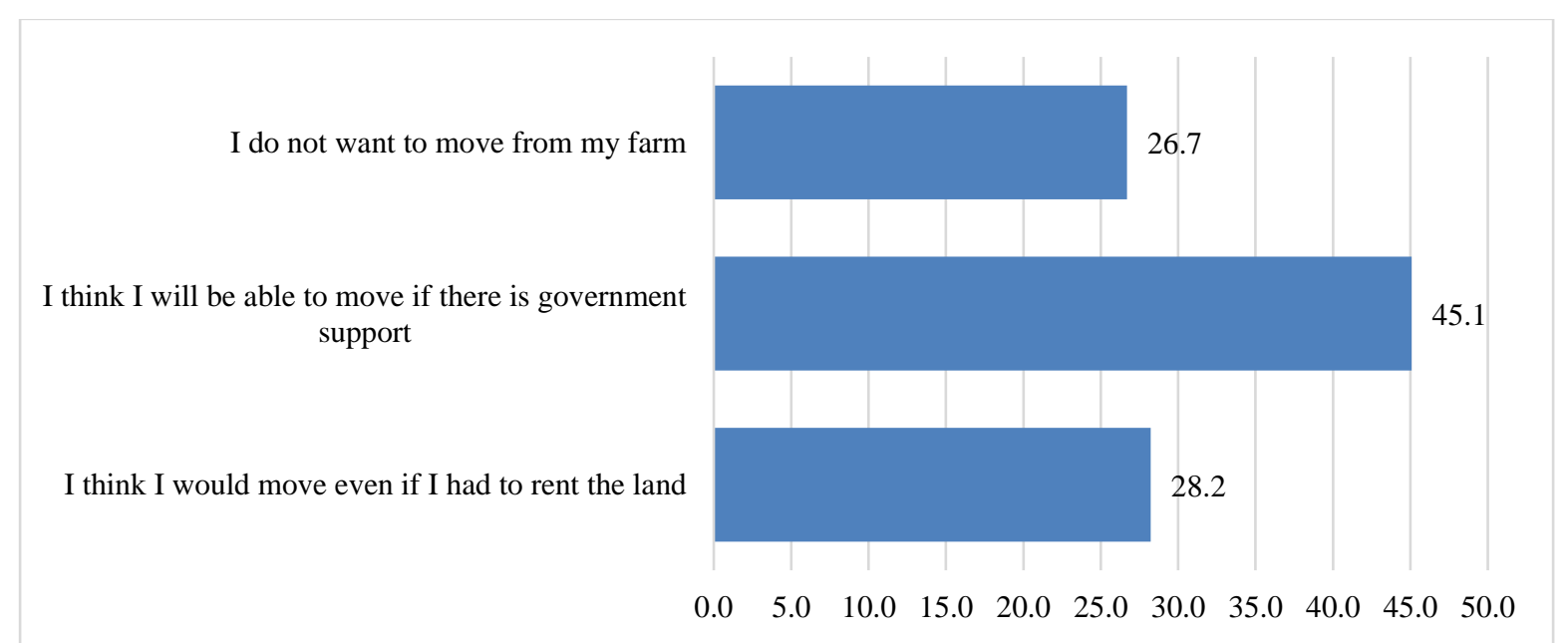

Figure 3: Share and conditions of household willingness to move 
S. Afr. J. Agric. Ext.

Vol. 47 No. 2, 2019: 81 - 93

http://dx.doi.org/10.17159/2413-3221/2019/v47n2a505
Zantsi, Greyling,

Vink

(License: CC BY 4.0)

\section{CONCLUSION AND RECOMMENDATIONS}

The objective of this study was to improve our understanding of the diversity among emerging farmers using various classification measures. This was motivated by the inconsistent use of the term, 'emerging farmer', the importance of emerging farmers in transforming the South African agricultural sector, and the potential contribution of emerging farmers to rural economy. Five commonly used measures which are used to describe emerging farmers in the South African context were identified and applied. It was found that no single measure should be used as the definitive indicator, but all five collectively.

Furthermore, it was established that the profile of the typical emerging farmer in the Eastern Cape Province is a black male, situated in a former homeland, and is 58 years old. The typical farmer cultivates field crops as a secondary source of food and income, but keeps livestock as primary and secondary sources of income. The average emerging smallholder mostly grows maize for own consumption given a crop commercialisation index (CCI) of 0.66 and sells a greater portion of his cabbage and potatoes given a CCI of 0.73 and 0.83 respectively. The average emerging farmer earns a net income of R26 600 per year, but there is an income inequality among them since the most successful farmer earned 26.7 times the average income. This translates to a Ghini coefficient of 0.48 that is high by international standards, but low compared to the South African average of 63.1. When speaking to fellow farmers, it was found that $78 \%$ of the emerging farmers feel constrained by farming in a homeland, but only $72 \%$ would be willing to move from their homeland, with most (45\%) saying that they would only do so if they are provided with sufficient government support. It is of the utmost importance that project planners, the extension advisory service, and policy makers take differentiated views on smallholder farmers to ensure that projects are focussed to the needs of specific groups. This is especially important with respect to emerging smallholder farmers as they are an important pool of potential land reform participants.

\section{ACKNOWLEDGEMENTS}

The financial assistance of the National Research Foundation (NRF) towards this research is hereby acknowledged. Opinions expressed and conclusions arrived at are those of the researchers and are not to be attributed to the NRF.

\section{REFERENCES}

ALIBER, M. \& HART, T.G.B., 2009. Should subsistence farming be supported as a strategy to address rural food insecurity? Agrekon, 48(4):434-458.

ANDREW, M. \& FOX, R.C., 2004. 'Undercultivation' and intensification in the Transkei: A case study of historical change in the use of arable land in Nompa, Shixini. Dev. South Afr., 21(4):687-706.

BINSWANGER-MKHIZE, H.P., 2014. From failure to success in South African land reform. Afr. J. Agr. Resour. Econ., 9(4):253-269.

BUREAU FOR FOOD AND AGRICULTURAL POLICY (BFAP), 2017. Baseline report: Agricultural outlook 2017-2026. Pretoria, South Africa.

CONNOR, T. \& MTWANA, N., 2018. Vestige garden production and deagrarianisation in three villages in the Eastern Cape, South Africa. S. Afr. Geogr. J., 100(1):82-103. 
CONRADIE, B.I., 2007. What do we mean when we say casualization of farm workers is rising? Evidence from the fruit farmers in the Western Cape. Agrekon, 46(2):173-194.

COUSINS, B., 2010. What is a smallholder? Class-analytic perspective on small-scale farming and agrarian reform in South Africa. Working paper 16. Institute for Poverty, Land and Agrarian Studies, University of the Western Cape, South Africa.

COUSINS, B., 2015. 'Through a glass, darkly': Towards agrarian transformation in South Africa. In Land Divided, Land Restored. Land Reform in South Africa for the $21^{\text {st }}$ Century (pp.250-269). Auckland Park: Jacana.

DE BEER, L. \& TERBLANCHÉ, S.E., 2015. Improving the livelihoods of wool producers in a sustainable manner by optimizing the woolled sheep production systems within the communal farming area of the Eastern Cape. "A vision that is future directed". S. Afr. J. Agric. Ext. 43(2):105-122.

DE LA HEY, M. \& BEINART, W., 2017. Why have South African smallholders largely abandoned arable production in fields? A case study. J. South Afr. Stud., 43(4):753-770.

DEPARTMENT OF AGRICULTURE, FORESTRY AND FISHERIES (DAFF), 2015. Impact of the Comprehensive Agricultural Support Programme from its inception in 2004 to February 2013. Pretoria, South Africa.

DEPARTMENT OF RURAL DEVELOPMENT AND LAND REFORM, 2013. State Land Lease and Disposal Policy. Pretoria, South Africa.

DIAO, X., HAZELL, P. \& THURLOW, J., 2010. The role of agriculture in African Development. World Dev., 38(10):1375-1383.

DORFMAN, R., 1979. A formula for Gini coefficient. Rev. Econ. Stat., 61:146-149.

DUBE, L. \& GUVEYA, E., 2016. Determinants of agriculture commercialization among smallholders in Manicaland and Masvingo Provinces of Zimbabwe. Agric. Sci. Res. J., 6(8):182-190.

FOURIE, P.J., MAHLAKO, S.R. \& VAN DER WESTHUIZEN, C., 2018. Assessment of the management practices of emerging sheep production systems in the eastern Free State: can the extensionist make a difference? S. Afr. J. Agric. Ext., 46(2):57-68.

GEBREMEDHIN, B. \& JALETA, M., 2010. Commercialisation of smallholders: Does market participation translate to market orientation? Working Paper 22. International Livestock Research Institute, Nairobi, Kenya.

GOVEREH, J., JAYNE, T.S. \& NYORO, J., 1999. Smallholder commercialization, interlinked markets and food crop productivity: Cross-country evidence in eastern and southern Africa. Department of Agricultural Economics, Michigan State University, United States of America.

HALL, R., 2015. Who, what, where, how, why? The many disagreements about land redistribution in South Africa. In Land Divided, Land Restored. Land Reform in South Africa for the 21st Century (pp.130-148). Auckland Park: Jacana.

HAZELL, P.B.R., 2009. Asian Green Revolution. IFPRI Discussion Paper No. 0091. Washington, D.C., United States of America.

HENDRICKS, S., 2002. Expenditure elasticities and growth linkages for rural households in two areas of KwaZulu-Natal. PhD Thesis, University of KwaZulu-Natal. 
JALETA, M., GEBREMEDHIN, B. \& HOEKSTRA, D., 2009. Smallholder commercialisation: Processes, determination and impact. ILRI Discussion Paper No. 18. Nairobi, Kenya.

KHAPAYI, M. \& CELLIERS, P.R., 2016. Factors limiting and preventing emerging farmers to progress to commercial agricultural farming in the King William's Town area of the Eastern Cape province of South Africa. S. Afr. J. Agric. Ext., 44(1):25-41.

KIRSTEN, J.F., 2011. Most farmers in South Africa are small-scale. Farmers' weekly. Sep, 23:38.

KIRSTEN, J.F. \& VAN ZYL, J., 1998. Defining small-scale farmers in the South African context. Agrikon, 37(4):551-562.

LIPTON, M., 1977. South Africa: Two agricultures? In Farm labour in South Africa (pp.7285). Cape Town: David Philip.

MACHETE, C.L., 2004. Agriculture and poverty in South Africa: Can agriculture reduce poverty? Paper presented to The Overcoming Underdevelopment Conference. Pretoria, South Africa.

MACLEOD, N.D., MCDONALD, C.K. \& VAN OUDTSHOORN, F.P., 2008. Challenges of emerging livestock farmers in Limpopo Province of South Africa. Afr. J. Range For. Sci., 25(2):548-562.

MMBENGWA, V., NYHODO, B., MYEKI, L., NGETHU, X. \& VAN SCHALKVYK, H., 2015. Communal livestock farming in South Africa: Does this farming system create jobs for poverty stricken rural areas? Sylwan, 159(10):176-192.

MOHLATLOLE, R.P., DZOMBA, E.F. \& MUCHADEYI, F.C., 2015. Addressing production challenges in goat production systems of South Africa: The genomics approach. Small Rumin. Res., 131:43-49.

NATIONAL PLANNING COMMISSION (NPC), 2011. The National Development Plan: 2030. Pretoria, South Africa.

NGQANGWENI, S., 1999. Rural growth linkages in the Eastern Cape Province of South Africa. IFPRI Discussion Paper No. 33. Washington D.C., United States of America.

NIEUWOUDT, W.L., 2000. An economic evaluation of a crop insurance programme for smallscale commercial farmers in South Africa. Agrekon, 39(3):269-291.

PIENAAR, L. \& VON FINTEL, D., 2014. Hunger in the former apartheid homelands: Determinants of convergence on a century after the 1913 Land Act. Agrekon, 53(4):3867.

PINGALI, P.L. \& ROSEGRANT, M.W., 1995. Agricultural commercialization and diversification processes and policies. Food Policy, 20(3):185-195.

ROSEGRANT, M.W. \& HAZELL, P., 2000. Transforming the rural Asian economy: The unfinished revolution. Hong Kong, Oxford University Press.

ROTHER, H.A., HALL, R. \& LONDON, L., 2008. Pesticide use among emerging farmers in South Africa: Contributing factors and stakeholder perspective. Dev. South Afr., 25(4):399-424.

SANDREY, R., PUNT, C., JANSEN, H.G. \& VINK, N., 2011. Agricultural trade and employment in South Africa. Working paper 30. OECD Publishing, Paris, France. 
SENYOLO, G.M., 2007. Factors distinguishing low turnover emerging farmers from high turnover emerging farmers in South Africa. MSc Thesis, University of Limpopo.

STATISTICS SOUTH AFRICA, 2016. Agricultural household community survey, March 2016. Pretoria, South Africa.

VAN AVERBEKE, W. \& MOHAMED, S.S., 2006. Smallholder farming styles and development policy in South Africa: The case of Dzindi irrigation scheme. Agrekon, 45(2):136-157.

VETTER, S., 2013. What are the costs of land degradation to communal livestock farmers in South Africa: The case of Herschel District in the Eastern Cape. PhD Thesis, Rhodes University.

VINK, N. \& VAN ZYL, J., 1998. Black disempowerment in South African agriculture: A historical perspective. In The agricultural democratization of South Africa (pp.61-70). Cape Town: Francolin Publishers.

VON BRAUN, J., 1995. Agricultural commercialisation: Impacts on income and nutrition and implications for policy. Food Policy, 20(3):187-202.

WORLD BANK, 2007. World Development Report (WDR) 2008: Agriculture for Development. Washington D.C., United States of America.

WORLD BANK, 2018. World Bank Databank. Washington D.C., United States of America.

XABA, T. \& DLAMINI, C.S., 2015. The Comprehensive Support Programme's (CASP) training and capacity building: An impact analysis on income levels of emerging farmers in Limpopo Province, South Africa. Am. J. Econ. Finance Manag., 1(3):153-163. 
